\title{
Fannie Mae, Freddie Mac, and Housing: Good Intentions Gone Awry
}

Lawrence J. White

Stern School of Business

New York University

Lwhite@stern.nyu.edu

\author{
Forthcoming in \\ America's Housing Market: A Case of Government Failure \\ edited by \\ Randall Holcombe and Benjamin Powell
}

Revised draft: 7/14/06

\begin{abstract}
$\underline{\text { Abstract }}$
The Federal National Mortgage Association (Fannie Mae) and the Federal Home Loan Mortgage Corporation (Freddie Mac) are the two dominant entities in the secondary market for residential mortgages in the United States. This chapter describes and discusses these two companies and their special status in the U.S. residential mortgage market and recommends their true privatization, as well as a set of additional reform measures that would improve the efficiency of housing construction and consumption in the U.S. economy. Along the way, we will address a number of major issues that concern housing and its special place in the political landscape of America.
\end{abstract}

JEL Classification Numbers: G21, G28

Keywords: Fannie Mae; Freddie Mac; government-sponsored enterprises; housing; residential mortgages; securitization; regulation 


\section{$\underline{\text { I. Introduction }}$}

The Federal National Mortgage Association (Fannie Mae) and the Federal Home Loan Mortgage Corporation (Freddie Mac) are the two dominant entities in the secondary market for residential mortgages in the United States. They are also special organizations, in many ways, and their dominance and large size owe much to their specialness.

This chapter will discuss and describe these two companies and their special status in the U.S. residential mortgage market, with the recommendation that their special status be terminated -i.e., that they be truly privatized. We also recommend a set of additional reform measures that would improve the efficiency of housing construction and consumption in the U.S. economy. Along the way, we will address a number of major issues that concern housing and its special place in the political landscape of America. ${ }^{1}$

\section{$\underline{\text { II. Fannie \& Freddie: The Basics }}$}

A. What they do.

As of year-end 2004, Fannie Mae (\$989 billion in assets) and Freddie Mac (\$795 billion in assets) were the fourth and sixth largest companies in the U.S., respectively, when ranked by assets. ${ }^{2}$ In addition, these two companies are the largest issuers of residential mortgage-backed securities (MBS): Fannie Mae had \$1,598 billion in MBS outstanding as of year-end 2005; Freddie Mac's outstanding MBS totaled $\$ 974$ billion.

1 This chapter draws heavily on White (1991, 2003, 2004, 2005, 2006) and Frame and White (2004, 2005, 2006); more extensive support and references for many of the points advanced in this chapter can be found in those publications.

${ }^{2}$ Citigroup, Bank of America, and JPMorgan Chase were the first three; and AIG was fifth. Asset data for Fannie Mae for 2005 are not currently available, because of the company's accounting difficulties that are described in the text below. 
These two large companies focus all of their business activity on the residential mortgage market. In that market, they do primarily two things:

(1) Fannie Mae and Freddie Mac create and issue MBS, by swapping their newly created MBS for the residential mortgages that have been originated by commercial banks, savings institutions, and mortgage banks. ${ }^{3}$ In essence, the MBS represent pass-through claims on pools of underlying residential mortgages. The holders of the MBS get the (passed-through) interest and principal payments of the mortgage borrowers, less a "guarantee fee" charged by Fannie Mae and Freddie Mac. ${ }^{4}$ The guarantees of the two companies protect the MBS holders against losses due to "credit risk" (i.e., against the possibility that the borrower fails to repay her mortgage loan). ${ }^{5}$ The mortgage originators can sell their swapped MBS into the secondary market for these securities or hold the MBS as relatively liquid assets in their portfolios.

(2) Fannie Mae and Freddie Mac buy their own MBS in the secondary market (as well as buying some "whole loan" mortgages directly from originators) and hold these mortgages ${ }^{6}$ in their portfolios as assets. These assets have been funded largely (97\%) by debt issued by the two companies and to a much lesser extent (3\%) by equity.

B. Who they are.

\footnotetext{
${ }^{3}$ Mortgage banks are originators of residential mortgages that typically sell the mortgages quickly into the secondary market rather than holding them in portfolio.

${ }^{4}$ In recent years the guarantee fees have been approximately 20 basis points (i.e., $0.20 \%$ ) on the unpaid balance of the underlying pool of mortgages.

${ }^{5}$ It is important to note that the MBS holder remains exposed to "market risk" -- largely the risk that interest rates will change, which will affect the value of the MBS in ways that will be discussed later in this chapter.

${ }^{6}$ When Fannie Mae and Freddie Mac buy back their MBS from the secondary market, they are effectively just holding the underlying mortgages, since their guarantee is then meaningless for themselves.
} 
Fannie Mae was created in 1938, under the auspices of the National Housing Act of 1934. Until 1968, Fannie Mae was formally part of the federal government, issuing debt and purchasing

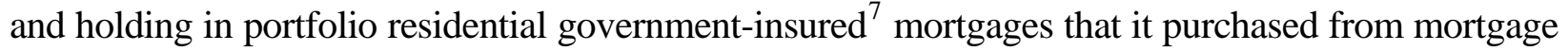
bank originators. In 1968, Fannie Mae was converted into a private corporation, with publicly traded shares listed on the New York Stock Exchange (NYSE), although it retained a unique federal charter with attributes that will be discussed below. ${ }^{8}$

Freddie Mac was created by act of Congress in 1970 to support mortgage markets by securitizing (i.e., issuing MBS) that were originated by savings and loan associations (S\&Ls). ${ }^{9}$ During the 1970s and 1980s, Freddie Mac was technically a private company, with its shares held by the 12 Federal Home Loan Banks (FHLBs) and by the S\&Ls that were members of the FHLB system. In 1989 Freddie Mac was converted into a publicly traded company, with shares listed on the NYSE and with the same special features (to be discussed below) as apply to Fannie Mae. ${ }^{10}$

Table 1 shows the major size dimensions of the two companies over the period 1971 - 2005. Especially noteworthy is the rapid growth of both companies between 1990 and 2000 and between

${ }^{7}$ Insured by the Federal Housing Authority (FHA), which was also created by the National Housing Act of 1934. After the Second World War, residential mortgages insured by the Veterans Administration (VA -- now, the Department of Veterans Affairs) also became eligible for purchase by Fannie Mae.

${ }^{8}$ Apparently, a major motive in this conversion to a private corporation was to remove Fannie Mae's debt from the national debt total. Fannie Mae was replaced within the federal government by the Government National Mortgage Administration (Ginnie Mae), an agency within the U.S. Department of Housing and Urban Development (HUD) that guarantees MBS that have as their underlying assets residential mortgages that are insured by the FHA or the VA.

${ }^{9}$ Ginnie Mae was the first issuer of MBS, in 1970. Freddie Mac was a fast second, with its first issuance in 1971. Fannie Mae's first MBS were issued in 1981.

${ }^{10}$ A major motivation for the conversion of Freddie Mac to a publicly traded company was the hope that wider holding of the company's shares would enhance the value of the shares then held by the ailing S\&L industry and thus strengthen the balance sheets of the latter. 
2000 and 2003. The reasons for that growth will be addressed below.

C. Their special features.

As was mentioned above, Fannie Mae and Freddie Mac are publicly traded companies, whose shares trade on the NYSE. They are, however, different from any other publicly traded company in the U.S., in a number of important ways:

- The corporate charter of each company is based on an act of Congress, rather than being granted by the corporation department of one of the 50 states;

- The President of the U.S. can appoint 5 of each company's 18 board members; ${ }^{11}$

- Neither company pays any state or local income taxes;

- The U.S. Treasury is authorized to purchase up to \$2.25 billion of each company's securities; $^{12}$

- The two companies' securities are "government securities" under the Securities Exchange Act of 1934;

- The two companies are not required to register their securities with the Securities and Exchange Commission (SEC); ${ }^{13}$ they are exempt from SEC fees;

- The two companies' securities can be purchased in unlimited quantities by banks and saving institutions; ${ }^{14}$

\footnotetext{
${ }^{11}$ For the past few years the Bush administration has refrained from making these appointments, as a way of separating itself from the two companies.

12 This is often described as the two companies' each having a line of credit of $\$ 2.25$ billion with the Treasury.

${ }^{13}$ Both companies have voluntarily pledged to do so. Fannie Mae has made good on its promise (before its accounting difficulties of 2004 caused great delays in the revelation of standard accounting information); Freddie Mac was enveloped in an accounting scandal in 2003 before it could follow through but is still committed to doing so eventually.

${ }^{14}$ Their securities are thus exempt from the "loans to one borrower" limitations that apply to all other loans and securities held by depository institutions.
} 
- The two companies' securities can be purchased by the Federal Reserve for open-market operations;

- The two companies can use the Federal Reserve as their fiscal agent; and

- The insolvency of either company must be resolved by the Congress, rather than by a regulator or by a bankruptcy court.

Virtually all of the above-listed features would be considered as advantages for the two companies. They are also subject to substantial limitations:

- The two companies are allowed to engage only in residential mortgage finance;

- The two companies cannot originate mortgages;

- The mortgages that the two companies can buy or securitize are subject to a maximum value (usually described as the "conforming loan limit"); for 2006 that ceiling is $\$ 417,000 ;{ }^{15}$

- The two companies are subject to "mission" regulation by HUD, which sets targets for "affordable housing" mortgages that the companies should purchase or securitize;

- The two companies are subject to "safety-and-soundness" regulation by the Office of Federal Housing Enterprise Oversight (OFHEO), ${ }^{16}$ which aims to keep them adequately capitalized and operating in a safe-and-sound manner (and thus to avoid their becoming insolvent); ${ }^{17}$ and

- The U.S. Treasury must approve all debt issuances by the two companies. ${ }^{18}$

15 The conforming loan limit is linked to an index of housing prices that is compiled by the Federal Housing Finance Board (FHFB). The value indicated in the text applies only to a mortgage on a single-unit residence; higher limits apply to mortgages on two-unit, three-unit, and four-unit dwellings and to mortgages for multifamily housing. Limits are $50 \%$ higher for Hawaii, Alaska, and the Virgin Islands.

${ }^{16}$ OFHEO is an independent regulatory agency that is structurally located within HUD.

17 Safety-and-soundness regulation has been practiced with respect to banks and other depository institutions for over two centuries. It was first instituted formally for Fannie Mae and Freddie Mac in 1992.

${ }^{18}$ Until 2006, the Treasury had routinely approved all of the two companies' debt issuances. In 


\section{The consequences.}

The two companies clearly have a special and extensive involvement with the federal government; $^{19}$ it is no accident that the two companies are often described as "governmentsponsored enterprises" (GSEs). As a consequence, the financial markets treat them in a special way: The two companies are able to borrow on more favorable terms (i.e., at lower interest rates) than their financial status would otherwise justify. Typically, the two companies can borrow at rates that are better than those that apply to a AAA-rated company (though not quite as good as the rates that apply to U.S. Treasury debt), even though the two companies' stand-alone (i.e., absent their special position) financial ratings would be about AA- or less. For their straight debt, this translates into about a 35-40 basis point advantage; ${ }^{20}$ similarly, for their MBS, they enjoy about a 30 basis point advantage.

In essence, their special status has convinced the financial markets that, in the event that either company were to be in financial difficulty and could not honor its obligations, the federal government would very likely step in and "bail out" the company (and thus bail out the company's creditors). ${ }^{21}$ This apparent belief by the financial markets has come to be described as the markets'

mid-2006, the Bush administration announced that it was exploring the possibility of using its potential disapproval power as a means of limiting the sizes of the two companies' mortgage portfolios, since those portfolios are funded almost entirely through debt issuances.

${ }^{19}$ As one reflection but also a reinforcement of this specialness, financial publications that report the prices and interest returns on the two companies' debt usually list them in a special box that is separate from listings of standard corporate debt. The Wall Street Journal, for example, lists their debt daily in a separate box that is labeled "Government Agency \& Similar Issues".

20 This differential varies over time, with financial conditions, and with the nature of the specific debt instrument being considered.

${ }^{21}$ Since the two companies cannot borrow on terms that are quite as favorable as those enjoyed by the U.S. Treasury, the phrase "very likely" rather than "definitely" seems appropriate. 
belief in an "implicit guarantee" by the federal government -- which is remarkable, since the legislative acts creating the two companies, as well as every one of their securities, carries explicit language that states that the two companies' securities are not the obligations of the U.S. Government. Counteracting this language, however, is the historical experience: In the late 1980s the Federal Government did provide a bailout for the Farm Credit System (which enjoyed similar special GSE benefits and relationships with the federal government); and in the late 1970s and early 1980s, though Fannie Mae was insolvent on a market-value basis, the federal government exercised forbearance and did not move to close or liquidate the company. Also, government officials -- even in the otherwise GSE-hostile Bush administration -- have not explicitly repudiated the "implicit guarantee". Instead, they have tiptoed around the subject, reminding the public that there is no explicit guarantee but not also stating that they would never consider a bailout.

To the extent that the financial markets are correct in their judgment, U.S. taxpayers are at risk in the event of financial difficulties at either company. ${ }^{22}$ This at-risk posture is a clear justification for OFHEO's safety-and-soundness regulation and highlights its importance. ${ }^{23}$

In turn, the two companies' activities in the secondary market for residential mortgages cause conforming mortgage loans to be about 20-25 basis points less than "jumbo" mortgages that are larger than the conforming loan limit. This reduction in the cost of mortgage borrowing (for conforming loans) is, of course, the primary reason for the two companies' creation by the Congress

${ }^{22}$ A rough measure of that exposure can be calculated by multiplying the borrowing advantages of the two companies (35-40 basis points on straight debt, 30 basis points on MBS) by the aggregate stocks of outstanding debt of the two companies. As of year-end 2005, this annualized aggregate exposure was around \$13-14 billion. The present discounted value of these annual flows -- the contingent liability to taxpayers -- would be around $\$ 200$ billion.

${ }^{23}$ An ironic consequence is that any strengthening of OFHEO's safety-and-soundness powers may well strengthen the financial markets' belief in an implicit guarantee. 
and the Congress's continuing support for them. ${ }^{24}$

In addition, the two companies' presence in the secondary mortgage market may well be a stabilizing influence. Historically, the two companies were able to bring greater uniformity and unification to what otherwise would have regionally fragmented mortgage markets, since during most of the twentieth century regulatory restrictions on interstate branching by banks and S\&Ls were present and prevented these institutions from bringing this unification. The two companies were also stabilizing influences in the mortgage markets immediately after the stock market free-fall of October 1987, the nervousness that accompanied the demise of Long Term Capital Management in September 1998, and the market distress that followed September 11, 2001. In addition, the two companies' size and importance in the secondary mortgage market may have caused them to be focal points for the standardization of mortgage origination and processing and for the transmission of technological advances in these areas. Finally, it is clear that (along with Ginnie Mae) Freddie Mac in the 1970s and then Fannie Mae also in the 1980s were important in the development of the secondary mortgage market and of mortgage securitization as an alternative mechanism for the financing of residential mortgages.

E. Why did they grow so fast?

The growth of the two companies between 1990 and 2000 and between 2000 and 2003 -- in terms of both their portfolios sizes and their stocks of outstanding MBS -- was truly breathtaking and warrants some further explanation.

There is little question that part of this growth was due to the blossoming of a new and efficient technology for financing residential mortgages: mortgage securitization. But there was more going on as well. Partly, the securitization process was aided by the capital requirements that

\footnotetext{
${ }^{24}$ As of 2003, this passed-through benefit was estimated to be worth approximately $\$ 13.4$ billion to homeowners.
} 
applied to banks and S\&Ls in their holdings of residential mortgages and MBS. For holding "whole loan" residential mortgages, the depository institutions were required to maintain $4 \%$ capital; for holding MBS, they were required to maintain only $1.6 \%$ capital. ${ }^{25}$ Though holding the GSEs' MBS meant that the depository institution also had to give up 20 basis points of yield (as payment to the GSEs for the latter's guarantees), the substantially reduced capital requirement usually more-thancompensated for the slightly reduced yield. Also, the MBS had a further advantage in being a more liquid and transactable asset than the equivalent pool of whole loan residential mortgages.

In addition, Fannie Mae and Freddie Mac were required to maintain only 2-1/2\% capital (as compared with the depositories' 4\% requirement) for holding mortgages in their own portfolios, and they could float debt with the 35-40 basis-point borrowing advantage discussed above, which gave them an advantage in acquiring mortgages and MBS for their own portfolios.

Finally, in 1989 Freddie Mac became a publicly traded company, and its senior management clearly saw rapid expansion, using high leverage ( $97 \%$ debt) and a favorable borrowing rate, as an excellent way to achieve rapid earnings growth for its shareholders. The senior management of Fannie Mae, after being traumatized by the high interest rates of the late 1970s and early 1980s, which meant that the market value of the company's mortgage portfolio shrunk below the value of its outstanding debt obligations, finally established a more solid financial foundation for the company and, like Freddie Mac, saw rapid, leveraged growth as the way to earn high and growing returns for the company's shareholders.

\section{F. Recent events.}

In early 2003 Freddie Mac's new external auditor (PriceWaterhouseCoopers) ${ }^{26}$ raised

25 The 1.6\% capital requirement applies to all GSE MBS and to any "private label" MBS (i.e., issued by companies other that the GSEs) that is rated AA or better.

${ }^{26}$ Freddie Mac's previous auditor had been Arthur Andersen. With Andersen's post-Enron indictment and demise, the company switched to PWC. It is often the case that a new auditor looks 
substantial questions about the company's accounting practices. These questions eventually led to the removal of the company's senior management and an agreement with OFHEO to maintain higher levels of capital than had previously been necessary, which effectively brought the company's rapid growth to a halt.

The accounting scandal at Freddie Mac clearly took OFHEO by surprise. The senior management of the agency then decided that a closer look at Fannie Mae's accounting was warranted, which led to the agency's determination in September 2004 that Fannie Mae's accounting too was seriously flawed. The company appealed this decision to the Securities and Exchange Commission, which sided with OFHEO. In early 2005 the senior management of the company was removed, and it too agreed to higher capital levels, which necessitated slower growth and actual shrinkage of assets.

In an important sense, the accounting scandals at the two companies were "sideshows" with respect to the important policy and regulatory issues that are the subject of this chapter. But the scandals did embarrass the two companies' political allies and provided the companies' critics with the opportunity to be able to say, in essence, "Look, things can go wrong at these two companies, and the next time the mistakes may be at the taxpayers' expense." Also, in both cases, OFHEO negotiated agreements that required the companies to maintain higher levels of capital, which slowed the companies' growth. ${ }^{27}$

\section{The Major Issues}

A. Housing and home ownership.

The special position of Fannie Mae and Freddie Mac is not an incidental or accidental

harder at some things than did the former auditor.

27 And, more specifically, in May 2006 OFHEO negotiated an agreement with Fannie Mae whereby the latter agreed to freeze its portfolio size at $\$ 727$ billion of an indefinite period. 
feature of government policy. Instead, the two companies' GSE status can be understood as part of a larger mosaic of efforts by governments at all levels in the U.S. to encourage housing consumption and home ownership. This wide range of government policies, past and present, has included:

- Tax advantages: the exclusion of the implicit income from housing by owner-occupiers for income tax purposes while allowing the deduction of mortgage interest and local real estate taxes; the partial exemption of owner-occupied houses from capital gains taxes; accelerated depreciation on rental housing; and special tax credits, exemptions, and deductions;

- Rent subsidization programs;

- Subsidization of home down payments;

- Direct government provision of rental housing ("public housing");

- Mortgage insurance provided by FHA and VA;

- Securitization of FHA- and VA-insured mortgages by Ginnie Mae;

- Securitization of conforming mortgages by Fannie Mae and Freddie Mac;

- Purchases of conforming mortgages for portfolio holdings by Fannie Mae and Freddie Mac;

- Separate depository charters for S\&Ls, with mandates to invest in residential mortgages;

- Favorable funding for savings institutions and other depositories that provide substantial residential mortgage lending through membership in the Federal Home Loan Bank (FHLB) system (another GSE); and

- Federal deposit insurance for savings institutions and other depositories whose portfolios contain some residential mortgages.

"Too much is never enough" seems to be a fitting description for government policies toward housing.

The motives and goals for this broad array of policies are also broad and varied. Partly, 
housing can be a component of direct in-kind redistribution of income toward lower income households (although this motive cannot justify the various income tax exclusions, exemptions, and deductions, which benefit primarily higher income households). Partly, enhanced sales revenues and employment for the residential construction industry (i.e., the home builders and their employees) and their complementary industry allies (e.g., real estate brokers, mortgage lenders, mortgage brokers, building materials suppliers, etc.) provide a powerful political base. And, partly, encouraging home ownership is seen as an important social/political goal (although policies that encourage rental housing would seem to be in conflict with that goal).

It is this last motive -- encouraging home ownership -- that is most closely associated with Fannie Mae and Freddie $\mathrm{Mac}^{28}$ (as well as with the income tax deduction for owner-occupiers' mortgage interest and local real estate taxes and their partial exemption from capital gains taxes) and is thus worth addressing.

There are good theoretical arguments to support the idea that encouraging home ownership is a worthwhile goal. In principle, an owner-occupier can internalize the potential conflicts that can arise (because of asymmetric information problems) between tenant and landlord. Further, and more important from a social perspective, an owner-occupier household is more likely to become community-minded. Over the past decade a small but important empirical literature has developed that provides evidence-based support for these logical but previously unsupported arguments. In addition, home ownership has often provided a means for households to amass wealth: through the forced saving that occurs through the repayment of principal on a mortgage, and through the postWorld War II phenomenon of generally rising home prices.

One should hasten to add that home ownership is not, and should not be, for everyone. A house is a large, relatively illiquid asset. The transactions costs of buying and selling are large. As a

\footnotetext{
${ }^{28}$ Although both companies also buy and securitize mortgages on multi-family rental housing.
} 
consequence, home ownership can impede labor force mobility when the best employment opportunity for an individual would necessitate moving (and incurring those large transaction costs). Also, house prices do not always rise in all periods in all geographic areas. Finally, some households may not have the steady income and/or the budgetary habits and discipline to be able to make the regular periodic mortgage payments that are required of homeowners.

Nevertheless, there clearly are net positive aspects to home ownership that extend beyond just the private gains to the home-owning household that could justify some social encouragement.

The logical implication of this line of argument is that social policy should focus on providing help at the margin -- a monetary "nudge" that would push low- and moderate-income households that are on the cusp of a decision as to whether to stay as renters or to become homeowners to take the latter course of action. This nudge could take the form of assistance with a down payment or with monthly mortgage payments, or both. In essence, social policy should operate in a focused manner in the area that matters.

Though there are such focused programs, ${ }^{29}$ the major forms of government assistance for housing mentioned above operate instead on a broad-swath basis -- largely encouraging households who would likely buy anyway to buy a larger, better-appointed house on a larger lot (or to buy a second home). Since it is the act of being an owner-occupier that likely creates the positive externalities for a community, while the extent or amount of ownership would likely provide (at best) only secondary social benefits, such programs are extremely wasteful in terms of actually

${ }^{29}$ The FHA and VA mortgage programs have limits that are 50-60\% of the conforming loan limits for Fannie Mae and Freddie Mac, and thus these former programs tend to serve lower income households. Also, at the end of 2003 the Congress enacted the American Dream Downpayment Act, which authorized \$200 million annually to help low- and moderate-income homebuyers. This latter amount is only a small fraction, however, of the annual benefits that accrue mostly to upper-income homeowners through the various tax advantages of home owning, as well as through the activities of Fannie Mae and Freddie Mac. 
achieving the stated goal of encouraging more widespread home ownership. ${ }^{30}$ Indeed, research over the past few decades has indicated that too much of the capital stock of the U.S. has been devoted to housing, at the expense of investments in physical industrial capital and human capital, with aggregate U.S. income suffering as a consequence. And since the tax-based incentives operate through deductions and exemptions (rather than tax credits), which are worth more to upper-income households with higher marginal tax rates, it is clearly not the low- and moderate-income households who are the major beneficiaries of these programs.

The Fannie Mae and Freddie Mac structure is in this broad-brush tradition, rather than being tightly focused. Recall that the conforming loan limit for 2006 is $\$ 417,000$. This size mortgage, plus a 20\% down payment, would allow a buyer to purchase a $\$ 521,000$ home. Except for the "hot" real estate markets along the Atlantic and Pacific coasts, a $\$ 521,000$ house would be considerably above average in most American communities.

This last point can be made more specific by using slightly historical data. In 2004 the conforming loan limit for Fannie Mae and Freddie Mac was $\$ 333,700$, which would support the purchase of a $\$ 417,000$ house. In that year the median price of a new home that was sold in the U.S. was only $\$ 221,000$; the median price of an existing home that was sold was $\$ 184,000$. Thus, the housing that can be bought through a Fannie Mae or Freddie Mac mortgage far exceeds what is likely to be bought by a first-time low- or moderate-income household home buyer.

Of course, the two companies do also cater to low- and moderate-income households. HUD has set targets for their efforts with respect to "affordable housing", and the two companies have met those targets. ${ }^{31}$ But the bulk of their mortgage purchases are not focused on the group that ought to

\footnotetext{
${ }^{30}$ And, of course, programs that encourage the expansion of the supply of rental housing may actually discourage the spread of home ownership.

${ }^{31}$ It is worth noting that the two companies get credit toward meeting those targets by purchasing mortgages on affordable rental housing -- which, of course, does nothing to encourage home
} 
be the target of ownership-encouraging activities. Indeed, when HUD in 2004 decided to ratchet-up these targets, a major support for this ratcheting was HUD's findings that the two companies' mortgage purchases of loans for low- and moderate-income households and for first-time buyers were below (on a percentage basis) those of all lenders for comparable residential mortgages. Consistent with this, it appears that the activities of the two companies have had little or no effect on the rate of home ownership in the U.S.

In sum, the aggregate of housing policies in the U.S. have encouraged this country to overinvest in housing at the expense of other goods and services. The programs involving Fannie Mae and Freddie Mac have contributed to this over-investment in housing, while also not doing an especially good job of focusing on the low- and moderate-income first-time home buyer where the social argument for encouraging home ownership is the strongest.

\section{B. Safety-and-soundness regulation.}

To the extent that the financial markets are correct in their belief in the "implicit guarantee" by the federal government of the two companies' debt issuances -- i.e., that in the event that either company experienced financial difficulties and could not honor its obligations, the federal government would "bail out" the company (or, really, the company's creditors) -- then the creditors will not monitor the companies as carefully as if the creditors believed that they would be fully exposed to any losses. In turn, this reduced monitoring would encourage the companies' managements to undertake riskier activities (than if they were more closely monitored), since the companies' owners would benefit from the "upside" of risky outcomes, while (because of the protections of limited liability) being buffered from the full consequences of the "downside" losses. The creditors' implicit guarantor -- the federal government -- is thus exposed to potential losses from such "moral hazard" behavior.

ownership and may even discourage it. 
This problem of creditors exposed to moral hazard behavior by corporate managers is a general problem in a limited liability context. For most companies, lenders long ago came to understand this problem and learned how to protect themselves -- e.g., through limitations on managements' actions that are embodied in bond covenants and banks' lending agreements, as well through direct monitoring arrangements. For banks and other depository institutions, where the creditors (i.e., depositors) are considered to be less able to protect themselves and the adverse consequences of the institution's insolvency are likely to be substantial, the states and the federal government have long understood that safety-and-soundness regulation ${ }^{32}$ ought to be the public sector's counterpart to those private lenders' monitoring arrangements. Similar arguments underlie the states' safety-and-soundness regulation of insurance companies.

The federal government's exposure to potential losses from excessive risk-taking by Fannie Mae and Freddie Mac would logically call for a formal regime of safety-and-soundness regulation that would apply to the two companies. Only in 1992, however, did the Congress come to this realization, by enacting the Federal Housing Enterprises Financial Safety and Soundness Act. That Act created the Office of Federal Housing Enterprise Oversight (OFHEO), lodged in HUD, as the safety-and-soundness regulator of the two GSEs and instructed the agency to develop a set of forward-looking risk-based capital requirements that would apply to them. The agency required ten years before it was able to issue a final set of risk-based capital rules. That delay, plus Fannie Mae's revelation of a large exposure to interest-rate risk in 2002 and Freddie Mac's revelation in 2003 of an accounting scandal that required large revisions in its statements of recent years' income and balance sheet values, ${ }^{33}$ reinforced a general perception that OFHEO was a weak and less than fully effective

\footnotetext{
${ }^{32}$ This is a shorthand phrase that describes regulatory efforts to maintain the solvency of financial institutions through minimum capital (net worth) requirements, limitations on risky activities, and managerial competence requirements.

33 The scandal led to the departure of the senior management of the company.
} 
financial regulator. Though the agency gained a great deal of credibility through its vigorous investigation of Fannie Mae's accounting and the revelation in 2004 that the company too had manipulated its income statements and balance sheet values, ${ }^{34}$ it has nevertheless been clear that the agency requires strengthening.

Some of the proposals that have been actively considered include:

- Moving the agency out of HUD (where the culture is focused on housing, and safety and soundness is a secondary consideration) and into the Treasury (where the culture is more focused on safety and soundness);

- Moving the agency out of the executive branch entirely and establishing it as a freestanding "independent" regulatory body, where it would be less susceptible to direct White House influence;

- Bringing the FHLBs, which are also GSEs and are currently regulated by a separate (and frequently criticized) agency -- the FHFB -- under the aegis of whatever agency emerges from the legislation;

- Strengthening the agency's ability to levy fees on Fannie Mae and Freddie Mac and thereby allowing it to fund itself in a way that would put it less at the mercy of the political vagaries of Congressional budgetary appropriations;

- Giving the agency full authority to revise the minimum capital requirements that the two companies must meet;

- Giving the agency a role in the setting of the social targets that the two companies must meet; and

- Giving the agency the power to appoint a receiver that could liquidate or otherwise dispose of either company's assets in the event that the company was unlikely to meet its minimum capital requirements and thus was perilously close to insolvency.

\footnotetext{
${ }^{34}$ This scandal too led to the departure of the company's senior management.
} 
Though these proposals have been actively considered by the Congress for well over two years, and the two companies' formidable lobbying powers (that would oppose stronger regulatory restrictions) were thought to be considerably weakened by the accounting scandals that engulfed first the one company and then the other, and the Bush administration has made regulatory reform a high priority, no legislation had been passed as of the summer of 2006.

\section{Systemic risk.}

As the two companies have grown substantially larger, concerns about the consequences of their size for systemic risk have increasingly been voiced, accompanied by proposals that would impose severe limits on the sizes of the two companies' mortgage portfolios. Systemic risk refers to the "system" effect that a financial failure of either company could have on mortgage markets generally or on financial institutions specifically. In an important sense, this is an adjunct to the safety-and-soundness issue, since how strongly one feels about the systemic risk issue should logically be linked to how one feels about the strength of the safety-and-soundness regulatory system.

The two companies are exposed primarily to two kinds of risk: credit risk, which is the risk that the underlying mortgage holder defaults on her mortgage (and the repossessed home is worth less than the value of the mortgage); and market risk, which is primarily the risk that interest rates change after the company has invested in a mortgage at a fixed interest rate. Credit risk applies to all of the mortgages associated with the two companies -- those that they hold in portfolio and those that they securitize, since they offer guarantees to the holders of the latter. Market risk applies only to the mortgages that the two companies hold in their portfolios, since the holders of the MBS are holding a pass-through instrument and thus are the ones who are exposed to the interest rate risk on the underlying mortgages. 
Credit risk is generally considered to be the lesser of the risks facing the two companies. ${ }^{35}$ For the sixty years following the end of World War II, American housing markets have generally been strong, and housing prices have generally moved upward. The two companies' portfolio holdings and MBS are a large and nationally diversified stock and thus are unlikely to be seriously affected by scattered localized downturns. Further, the underwriting criteria used by mortgage originators -- primarily adequate household income and a good credit history, supported by an appraisal on the house -- are a good initial screen to protect the lender (or guarantor) against default. Also, the initial down payment of (typically) 20\%, or mortgage insurance provided by a third party if the down payment is less than $20 \%$, provides an initial buffer of protection.

Consistent with this optimistic picture, the credit losses by the two companies over the years 1987-2005 averaged less than 5 basis points (i.e., less than 0.05\%) annually on their total exposure; for the years 1999-2005, their credit losses averaged only 1 basis point annually. Of course, if the U.S. economy were to experience the upheavals and collapse of housing prices and household incomes that occurred during the Great Depression, credit losses would be considerably higher. Still, credit losses are not where the concerns have been focused.

Instead, attention has centered on the two companies' market risk, which is exacerbated by the fact that the long-term fixed-rate mortgages that they hold can all be pre-paid by the borrowers with no penalties. The holder of a long-term fixed-rate debt instrument generally experiences a capital loss when interest rates rise but experiences a capital gain when interest rates fall. Prepayable mortgages, however, are more likely to be pre-paid and refinanced (at the newly lower interest rates) when interest rates decline, so that the holder of the mortgage (or MBS) is less likely to experience a capital gain.

\footnotetext{
${ }^{35}$ Consistent with this argument, the size limits that have been proposed for the two companies have applied only to their holdings of mortgage assets and not to their MBS issuances.
} 
The two companies each have over $\$ 700$ billion in residential mortgages in their portfolios, largely in the form of long-term fixed-rate mortgages that can be prepaid by the borrower at any time without a prepayment penalty. To some extent the companies offset this risk by issuing callable debt (so that, as mortgages prepay, the companies can call in the debt that has funded the mortgages). In addition, they use derivative instruments, such as interest-rate swaps and options on swaps, to construct obligations that largely match the profile of their mortgage assets.

The fears of critics is that this hedging process might go awry -- because of sloppiness or cutting corners or counterparty failures. In that event, there surely would be effects on the mortgage and debt markets, because of the sheer size of the companies' portfolios and because even the holders of their MBS could become nervous. The size of the impact would depend on the extent of the apparent losses, on whether there would be a "contagion" effect that would affect the other company even if only one of the two initially experienced difficulties, and on how quickly the other major "players" in the mortgage markets could expand to take up the slack. ${ }^{36}$ Because there never has been such an event, it is difficult to estimate how serious the effects on the residential markets would be.

D. Efficiencies and Inefficiencies.

Are the two companies efficient organizations for doing what they do? In an important sense, there is no "market test" for finding out the answer to this question. The Congress chartered only the two companies with their specific characteristics and special privileges. The ability of competitive processes to winnow inefficient firms from the marketplace is thereby inhibited. Though the FHLB system -- another GSE -- has entered the secondary residential mortgage market within the last decade, recent expansion by the FHLBs has been inhibited by capital limitations and

\footnotetext{
${ }^{36}$ Although banks and S\&Ls are relatively large holders of the two companies' securities, it does not appear that a financial crisis by either company would cause a serious cascade of depository insolvencies.
} 
some accounting difficulties of their own.

Further, the two companies are not required periodically to rebid for their franchises against potential replacements. In essence, they have been "grandfathered" indefinitely with respect to their special charters. Also, the market for corporate control cannot operate effectively: Their limited charters make them immune to takeover by any other firm, and their large size and special GSE status make them virtually immune to a "hostile" takeover by an outside investor group. Major accounting scandals and OFHEO pressure were required to remove the two companies' senior managements in the past few years.

As a related matter, any time that the two companies have attempted to expand either "horizontally" (e.g., into "subprime lending") or "vertically" (e.g., into providing underwriting software to mortgage originators) -- or have contemplated such expansions -- rivals have cried "foul" and complained that the companies' expansions were possible only because of their special borrowing advantages and not because of inherent synergies or efficiencies. Without a "clean" market test, there is no easy way to resolve such questions.

\section{What Is to Be Done?}

\section{A. First-best.}

If there ever was a good social reason for the special GSE status of Fannie Mae and Freddie Mac -- arguably, they helped unify local and regional mortgage markets at a time when banks and S\&Ls could not due to regulatory barriers, and their special GSE status may well have helped the worthwhile technology of mortgage securitization gain traction in the financial markets -- that time has since passed. Sunk benefits are sunk! Securitization is now a well-established technology that other financial institutions handle routinely. And mortgage markets are now integrated because of the active secondary market (which would survive in the absence of the two companies' special 
status) and because depositary institutions can now branch nationwide.

As has been argued above, the two companies are primarily a part of the broad-brush American policies that encourage over-consumption of housing at the expense of alternative uses of the resources, and they are not especially good in the area where their social value would be the highest: encouraging low- and moderate-income households who are on the cusp to become firsttime home buyers. Accompanying the two companies' GSE status has been the financial markets' belief that, in the event that either company experienced financial difficulties, the federal government would very likely bail out the company's creditors, thus exposing the government and ultimately the nation's taxpayers to a substantial contingent liability.

Though the idea of enlisting the private sector and its efficiencies for the pursuit of social goals has attractive aspects, there are rarely free lunches to be enjoyed. In this case, too much housing has been encouraged, and the shareholders of the two companies have enjoyed substantial gains while taxpayers have been exposed to the risks of a sizable contingent liability. This policy of "privatizing the gains, socializing the losses" is not an attractive one.

Accordingly, the first-best policy would be to privatize them fully. This would mean that the Congress should enact legislation that would eliminate all of the special features that were outlined in Section II, and the two companies would be told to seek a state corporate charter (probably from Delaware), just like any other corporation. ${ }^{37}$ In essence, their past and present senior managements would be (literally and figuratively) publicly patted on the back for a job well done in bringing about securitization and the national integration of residential mortgage markets (but not for the accounting scandals) and then pointed toward the office of the secretary of state in Dover, Delaware, to seek a corporate charter.

At the Congressional hearings on this legislation (and on all other opportunities), the

\footnotetext{
${ }^{37}$ The same treatment should apply to the FHLB system.
} 
Secretary of the Treasury should loudly proclaim that henceforth (following enactment) the two companies will be treated just like any other private-sector company, with no special treatment from the Treasury, and that the bankruptcy laws should apply in the event that they experience financial difficulties. At the official signing of the legislation, the President should repeat this message. ${ }^{38}$

Note that this true privatization does not mean the demise or disappearance of the two companies. They appear to be generally good at what they do (notwithstanding their accounting failures); but they should be doing it in a context where their owners and creditors bear the full risks of the companies' actions, rather than the taxpayers bearing those risks, and where they will be subject to a full market test to see how well they really do. The companies would begin their fully private experience at their current sizes, which (arguably) would give them some advantages. But without their special status, their borrowing costs should rise to be commensurate with their standalone status (i.e., AA-), and/or they will raise more (costly) capital so as to improve their financial status and keep their borrowing costs low and/or make other adjustments in their financial structure and activities. Over time their presence in the residential mortgage markets would shrink somewhat (as a consequence of their higher borrowing costs); but freed from the restraints that currently confine them to the secondary mortgage market, they might well apply their expertise to related markets, such as consumer lending, mortgage insurance, or even mortgage origination.

As a further consequence, interest rates on residential mortgages (below the conforming loan limit) would rise by approximately 20-25 basis points. This is well within the range of annual variations in mortgage interest rates and would be easily accommodated. Grass would not grow in

${ }^{38}$ Lest anyone think that this true privatization would cause an overnight crisis in the financial markets, it is worth emphasizing that any such effort would likely require years in going from initial consideration (e.g., a Presidential task force formation and then subsequent recommendation, Congressional hearings, etc.) through eventual Congressional passage and final signing. The financial markets would have plenty of time gradually to adjust their beliefs as to the likelihood that this idea would be converted into reality. 
the streets of America; and grass would continue to grow in most backyards in America. Ironically, since much of what the 20-25 basis point reduction in mortgage interest rates does is to encourage excessive investment in and consumption of housing, this price increase would represent a net improvement in the use of the American economy's resources.

As a more focused and efficient way of encouraging home ownership Congress should enact legislation that would expand on the American Dream Downpayment Act of 2003 in place of the special status of Fannie Mae and Freddie Mac. More funds could be made available for down payment assistance for low- and moderate income first-time home buyers, and assistance for monthly payments could also become part of the program. Not only would an expansion of this program better serve the social goal of encouraging home ownership in the U.S., but this would be in the form of an explicit on-budget program (rather than the implicit off-budget contingent liability approach that the GSE route represents) -- always a better way for government to operate.

Further, as a way to reduce the costs of building and buying housing, more attention should be given to other government policies that restrict supply and elevate costs. Prime candidates at the national level would be: 1) eliminating restrictions on the import of lumber from Canada; 2) eliminating restrictions on the import of cement from Mexico; 3) reforming the Real Estate Settlements Practices Act of 1974 in ways that would allow more competition and efficiencies and yield lower charges for closing costs on home purchases; and 4) allowing banks and other depositories to enter real estate brokerage, so as further to reduce the transactions costs on home purchases. At the state and local level, prime candidates would be: 1) repealing state policies that restrict competition in real estate brokerage; 2) repealing state policies that prevent lenders from charging fees for mortgage prepayments; ${ }^{39}$ 3) eliminating inefficient local building codes that raise

${ }^{39}$ Requiring that lenders allow all mortgage borrowers to have the free option of prepaying their mortgage means that the interest rate risk borne by lenders is increased. To compensate for that risk, lenders raise the interest rates on all such mortgages. If lenders could explicitly price the prepayment option, mortgage interest rates would generally be lower, and only those who prepaid 
the cost of building local housing by more than safety or similar considerations warrant; and 4) repealing local large-lot zoning measures that restrict the availability of land for lower-cost, higherdensity housing in areas where land would otherwise be inexpensive.

\section{B. Second-best.}

The true privatization of Fannie Mae and Freddie Mac is probably a quixotic dream in the current political environment. The political attractiveness of an arrangement that reduces housing costs with no apparent on-budget consequences is understandable. Indeed, it is remarkable that, despite the accounting scandals that beset the two companies and their apparent consequent political weakening, there has been no regulatory reform legislation that has been enacted as of the summer of 2006.

Accordingly, consideration of second-best measures is worthwhile:

First, even in the absence of the privatization of the two companies, an expansion of onbudget programs to help low- and moderate-income first-time home buyers would be worthwhile, as would all of the efforts to decrease the artificially raised costs of building and buying housing that were described above.

Second, the Secretary of the Treasury should proclaim loudly, at frequent intervals, that it is the policy of the federal government to adhere to what is explicitly stated on the two companies' securities: that these are not the obligations of the U.S. Government and that the government has no intention of ever "bailing out" the two companies or their creditors.

Third, the two companies' residential mortgage purchases should be restricted to mortgages on single-family homes. Their purchases of mortgages on multi-family (rental) housing do nothing to encourage home ownership and may even discourage it.

Fourth, in addition to keeping and possibly even increasing the pressures of HUD's

would bear the cost. 
"mission" regulation to keep the GSEs focused on affordable housing, ${ }^{40}$ the "conforming loan" ceiling should be frozen at its current level until the median sales price of housing (or, really, $80 \%$ of the median sales price) catches up to that level. Even better would be a steady rollback toward the median. Any narrowing of the gap between the conforming loan limit and the median price of housing would more directly focus the two companies on the segment of the housing market where their social value would be the greatest. It would also have the beneficial effect of limiting the two companies' growth and portfolio sizes and thereby easing potential systemic risks. ${ }^{41}$

Fifth, banking regulators should repeal the special exemption from the "loans to one borrower" rules that applies to banks' and S\&Ls' holdings of the two companies' debt.

Sixth, the safety-and-soundness regulatory regime that applies to the GSEs should be strengthened. OFHEO (or a successor agency) should be moved from HUD into the Treasury. ${ }^{42}$ The agency should be granted explicit receivership powers and the ability independently to set riskbased capital requirements, as well as having a say in the development of any social goals.

\section{$\underline{\text { V. Conclusion }}$}

Housing is too important to be left to the gentle mercies of Fannie Mae and Freddie Mac in their current GSE form. There are far better ways to pursue the social goal of encouraging home

${ }^{40}$ Except that, consistent with the previous point, the GSEs' purchases of mortgages on multifamily (i.e., rental) housing ought not to be included.

${ }^{41}$ Freezing or decreasing the conforming loan limit would be a superior means of limiting the GSEs' mortgage portfolios, as compared with a simple limit on their portfolio sizes. The latter would create an incentive for them to concentrate more on the higher end of the mortgage market, where they could earn higher profits per dollar of their (limited-size) portfolios.

${ }^{42}$ Keeping the agency within the executive branch rather than moving it to a wholly independent status is worthwhile, because an executive-branch location focuses political responsibility and accountability. 
ownership in America. Truly privatizing the two companies, as well as pursuing a range of sensible reforms, would better encourage home ownership in ways that would improve the efficiency of the U.S. economy and increase social welfare and equity. There is no better time to start this effort than the present.

\section{References}

Frame, W. Scott and Lawrence J. White. 2004. Regulating Housing GSEs: Thoughts on Institutional Structure and Authorities. Federal Reserve Bank of Atlanta Economic Review 89 (second quarter): 87-102.

Frame, W. Scott and Lawrence J. White. 2005. Fussing and Fuming over Fannie and Freddie: How Much Smoke, How Much Fire? Journal of Economic Perspectives 19 (spring): 159-184.

Frame, W. Scott and Lawrence J. White. 2006. Charter Value, Risk-Taking Incentives, and Emerging Competition for Fannie Mae and Freddie Mac. Journal of Money, Credit, and Banking (forthcoming).

White, Lawrence J. 1991) The S\&L Debacle: Public Policy Lessons for Bank and Thrift Regulation. New York: Oxford University Press.

White, Lawrence J. 2003. Focusing on Fannie and Freddie: The Dilemmas of Reforming Housing Finance. Journal of Financial Services Research 23 (February): 43-58.

White, Lawrence J. 2004. Fannie Mae, Freddie Mac, and Housing Finance: Why True Privatization is Good Public Policy. Policy Analysis, No. 528. Washington, D.C.: Cato Institute (October 7).

White, Lawrence J. 2005. On Truly Privatizing Fannie Mae and Freddie Mac: Why It’s Important, and How to Do It. Housing Finance International 20 (December): 13-19.

White, Lawrence J. 2006. The Residential Real Estate Brokerage Industry: What Would More Vigorous Competition Look Like? Real Estate Law Journal 34 (Summer): 22-42. 
Table 1: Fannie Mae and Freddie Mac Assets and Mortgage-Backed Securities, and the Residential Mortgage Market (in billions of dollars)

\begin{tabular}{|c|c|c|c|c|c|c|c|}
\hline \multirow[b]{2}{*}{ Year } & \multicolumn{3}{|c|}{ Fannie Mae } & \multicolumn{3}{|c|}{ Freddie Mac } & \multirow[b]{2}{*}{$\begin{array}{l}\text { Total non- } \\
\text { farm, } \\
\text { residential } \\
\text { mortgages }\end{array}$} \\
\hline & $\begin{array}{l}\text { Total } \\
\text { assets }\end{array}$ & $\begin{array}{l}\text { Retained } \\
\text { mortgage } \\
\text { portfolio }^{\text {a }} \\
\end{array}$ & $\begin{array}{l}\text { Mortgage- } \\
\text { backed } \\
\text { securities } \\
\text { outstanding }\end{array}$ & $\begin{array}{l}\text { Total } \\
\text { assets }\end{array}$ & $\begin{array}{l}\text { Retained } \\
\text { mortgage } \\
\text { portfolio }^{\mathbf{a}} \\
\end{array}$ & $\begin{array}{l}\text { Mortgage- } \\
\text { backed } \\
\text { securities } \\
\text { outstanding }\end{array}$ & \\
\hline 1971 & $\$ 19$ & $\$ 18$ & $\$ 0$ & $\$ 1$ & $\$ 1$ & $\$ 0.1$ & $\$ 38$ \\
\hline 1975 & 32 & 31 & 0 & 6 & 5 & 2 & 575 \\
\hline 1980 & 58 & 56 & 0 & 6 & 5 & 17 & 1,100 \\
\hline 1985 & 99 & 94 & 55 & 17 & 14 & 100 & 1,724 \\
\hline 1990 & 133 & 114 & 288 & 41 & 22 & 316 & 2,903 \\
\hline 1995 & 317 & 253 & 513 & 137 & 108 & 459 & 3,727 \\
\hline 2000 & 675 & 608 & 707 & 459 & 386 & 576 & 5,581 \\
\hline 2001 & 800 & 707 & 859 & 641 & 504 & 653 & 6,019 \\
\hline 2002 & 888 & 801 & 1,030 & 752 & 590 & 730 & 6,731 \\
\hline 2003 & 1,010 & 902 & 1,300 & 803 & 661 & 752 & 7,581 \\
\hline 2004 & 989 & 905 & 1,403 & 795 & 665 & 852 & 8,642 \\
\hline 2005 & n.a. & 727 & 1,598 & 806 & 710 & 974 & 9,851 \\
\hline
\end{tabular}

Note: Includes single- and multi-family mortgages.

${ }^{a}$ Includes repurchased mortgage-backed securities.

b Excludes mortgage-backed securities that are held in the company's own portfolio.

Sources: Federal Reserve; OFHEO; Fannie Mae; Freddie Mac 